J. Dairy Sci. 95:5645-5656

http://dx.doi.org/10.3168/jds.2011-5113

(C) American Dairy Science Association ${ }^{\circledR}, 2012$.

\title{
Effects of lactation and pregnancy on metabolic and hormonal responses and expression of selected conceptus and endometrial genes of Holstein dairy cattle
}

\author{
I. M. Thompson, ${ }^{*}$ R. L. A. Cerri, ${ }^{\star} \dagger$ I. H. Kim, $\neq$ A. D. Ealy, ${ }^{\star}$ P. J. Hansen, ${ }^{*}$ C. R. Staples, ${ }^{\star}$ and W. W. Thatcher ${ }^{\star 1}$ \\ *Department of Animal Sciences, University of Florida, Gainesville 32611 \\ †Faculty of Land and Food Systems, University of British Columbia, Vancouver, BC, Canada V6T 1 Z4 \\ $¥$ College of Veterinary Medicine, Chungbuk National University, Cheongju, Chungbuk 361-763, Korea
}

\begin{abstract}
Objectives were to characterize postpartum metabolic and hormonal differences between nonlactating and lactating dairy cows, evaluate lactation and pregnancy effects on endometrium and conceptus expression of selected genes, and characterize associations between conceptus and endometrial expression of genes in early pregnancy (d 17). Pregnant heifers were assigned randomly after calving to a lactating group $(\mathrm{L}, \mathrm{n}=17)$ and a nonlactating group (NL, $\mathrm{n}=16$ ). The $\mathrm{L}$ cows were fed a total mixed ration [1.65 Mcal of net energy for lactation $\left(\mathrm{NE}_{\mathrm{L}}\right) / \mathrm{kg}, 16.5 \%$ crude protein $\left.(\mathrm{CP})\right]$ ad libitum, and the NL cows were fed a maintenance ration (1.45 Mcal of $\mathrm{NE}_{\mathrm{L}} / \mathrm{kg}, 12.2 \% \mathrm{CP}$ ) once per day. All cows were presynchronized and enrolled in a timed artificial insemination (TAI) protocol; 10 cows in the L and 12 in the NL received TAI. On d 17 after GnRH and TAI, cows were slaughtered and endometrial and conceptus tissues collected. The Affymetrix Bovine Genome DNA Microarray (Affymetrix Inc., Santa Clara, CA) was used to assess conceptus and endometrial gene expression. The L cows had higher body temperature than the NL cows $\left(38.4\right.$ vs. $\left.38.2^{\circ} \mathrm{C}\right)$, and the NL cows cycled earlier than the L cows (26.3 vs. $34.7 \mathrm{~d}$ in milk). Cows in the L group had greater plasma concentrations of $\beta$-hydroxybutyrate (4.90 vs. $2.97 \mathrm{mg} / \mathrm{dL}$ ) and blood urea $\mathrm{N}$ (11.6 vs. $6.5 \mathrm{mg} / \mathrm{dL})$ and lower concentrations of glucose (74.0 vs. $79.9 \mathrm{mg} / \mathrm{dL}$ ) compared with NL cows. Insulin-like growth factor-1 was lower for L compared with NL (140.5 vs. $198.2 \mathrm{ng} / \mathrm{mL}$ ) and was greater for cows subsequently classified pregnant compared with cyclic (191.0 vs. $147.6 \mathrm{ng} / \mathrm{mL}$ ). The concentration of progesterone from GnRH or TAI (d 0) until d 17 was lower for L cows than for NL cows. Gene expression analyses indicated that all conceptuses $(\mathrm{n}=13)$ expressed pregnancy-associated glycoprotein (PAG) genes
\end{abstract}

Received November 1, 2011.

Accepted May 29, 2012.

${ }^{1}$ Corresponding author: thatcher@ufl.edu
PAG2, PAG8, PAG11, and PAG12. The same PAG family genes were observed in the endometrium of some pregnant cows. Simple and standard partial correlation analyses detected associations of conceptus PAG11 with prostaglandin regulatory genes. In conclusion, lactation altered metabolic status, delayed initiation of cyclicity, and decreased concentrations of progesterone in pregnant cows. Early expression of $P A G$ genes in the conceptus may contribute to successful development of early pregnancy and possibly alter mechanisms related with embryo survival such as prostaglandin synthesis.

Key words: dairy cow, gene expression, lactation, pregnancy-associated glycoprotein

\section{INTRODUCTION}

In the past few decades, the shift toward more productive cows has been associated with a decline in fertility (Butler, 2005), which is partly explained by reduced fertilization and poorer embryo development in lactating dairy cows (Sartori et al., 2002). Studies comparing ovarian structures and circulating steroids of heifers, nonlactating cows, and lactating cows showed that, in general, lactating dairy cows ovulated larger follicles and formed larger corpora lutea (CL), despite having lower progesterone and estradiol concentrations (Sartori et al., 2004). This inverse relationship is probably due to greater steroid metabolism in lactating cows (Wiltbank et al., 2006).

Adequate synchronization of embryonic development and remodeling of the endometrium are crucial to support fetal-placental development throughout gestation and avoid pregnancy failure. Fetal-derived placental cells (trophoblast) fuse to the endometrium and deliver secretory products into the maternal system. Numerous molecules, including proteins, cytokines, hormones, and growth factors coordinate events at the fetal-maternal interface and systematically modulate maternal anatomy, endocrinology, immunology, and physiology to create an appropriate environment for conceptus development and survival (Bauersachs et al., 2006; Forde et al., 2010). 
In ruminants, among the molecules recognized as being synthesized and secreted by trophoblast cells are the pregnancy-associated glycoproteins (PAG), also known as pregnancy-specific protein B (PSPB; Butler et al., 1982) and pregnancy serum protein of molecular weight $60 \mathrm{kDa}$ (PSP60; Mialon et al., 1994). In cattle, 18 distinct $P A G$ genes and 14 pseudogenes have been identified (Telugu et al., 2009). The measurement of PAG protein in maternal blood can be a reproductive management tool for early pregnancy diagnosis in cattle and may be an indicator of embryonic and fetal well-being or pregnancy loss (Sasser et al., 1986; Patel et al., 1995; Kindahl et al., 2002; Ishiwata et al., 2003; Green et al., 2005; Thompson et al., 2010). Although the functional roles of these molecules remain unclear, it has been speculated that they are involved in adhesion, implantation, and remodeling of the fetal-maternal unit (Wooding et al., 2005), immune regulation (Austin et al., 1999; Dosogne et al., 1999; Hoeben et al., 1999), and prostaglandin synthesis and regulation (Del Vecchio et al., 1990; Weems et al., 1998a, 2003).

Fertilization in lactating dairy cows is estimated to be around $80 \%$, but only half of these embryos will survive 28 d later (Santos et al., 2004). A precise understanding of the dialog between embryo/fetal-maternal-placental units is needed to reduce early and late pregnancy losses in cattle. Thus, elucidating the mechanisms that control embryo and endometrial development in early gestation is important for identification of genes regulating implantation, placentogenesis, and maintenance of pregnancy.

The development of microarray analysis has provided an opportunity to study early gestation expression of several thousand genes simultaneously. We hypothesized that lactation would alter concentrations of key hormones and metabolites and cause differential expression of selected genes in endometrium and conceptus at d 17 after AI in both cyclic and pregnant cows. Therefore, the objectives of this study were to (1) characterize postpartum metabolic and hormonal differences between nonlactating and lactating dairy cows, (2) develop a physiological platform to evaluate lactation and pregnancy effects on endometrium and conceptus gene expression, and (3) characterize associations between conceptus PAG11 expression with other conceptus genes in early pregnancy (d 17).

\section{MATERIALS AND METHODS}

\section{Study Population}

The study was conducted at the University of Florida Dairy Unit. Thirty-nine pregnant Holstein dairy heif- ers purchased in New York were enrolled in the study. Heifers were evaluated for pregnancy and vaccinated at the time of arrival. All heifers were housed in sod-based pens at around 3 wk before expected calving and fed a close-up ration of $1.51 \mathrm{Mcal}$ of $\mathrm{NE}_{\mathrm{L}} / \mathrm{kg}, 15.2 \% \mathrm{CP}$, and a DCAD of $-4.5 \mathrm{mEq} / 100 \mathrm{~g}$. Heifers at calving ranged from 22 to 27 mo of age.

After calving, cows were randomly assigned into 2 treatment groups: nonlactating (NL) and lactating $(\mathbf{L})$ and moved to a freestall facility. The NL heifers were dried off immediately (i.e., not milked) after calving and the L cows were milked twice daily. Samples for measurement of milk protein and fat were collected once a month and analyzed by Southeast Milk Laboratory (Belleview, FL) using a Bentley 2000 NIR analyzer (Bentley, Chaska, MN). Cows in the NL group were fed a far-off dry cow ration (1.45 Mcal of $\mathrm{NE}_{\mathrm{L}} / \mathrm{kg}, 12.2 \%$ CP) consisting of $80 \%$ sorghum silage, $8.8 \%$ citrus pulp, $5 \%$ cottonseed meal, $5 \%$ molasses, and $1.2 \%$ mineral/ vitamin premix once per day to meet maintenance requirements. The L cows were fed a TMR (1.65 Mcal of $\mathrm{NE}_{\mathrm{L}} / \mathrm{kg}$ and $16.5 \% \mathrm{CP}$ ) consisting of $38 \%$ corn silage, $18 \%$ corn meal, $8 \%$ alfalfa hay, $6.9 \%$ corn gluten feed, $5.4 \%$ wet brewer grains, $5.2 \%$ soybean meal, $4.5 \%$ soyplus, $3.7 \%$ molasses, $3.3 \%$ citrus pulp, $3.3 \%$ whole cottonseed, and $3.7 \%$ of a mineral/vitamin premix with ad libitum access to feed and water. Of the 39 pregnant heifers enrolled, 4 were excluded from the experiment because of death or because they failed to complete the study due to major health disorders. Thus, 35 cows completed the study until slaughter.

\section{Study Design}

Lactating ( $\mathrm{L}, \mathrm{n}=18)$ and nonlactating ( $\mathrm{NL}, \mathrm{n}=$ 17) groups of cows were managed in separate pens. All cows were placed on a Presynch/CIDRSynch protocol (Figure 1). However, 10 cows in the $\mathrm{L}$ group and 12 in the NL group underwent timed AI (TAI) and the noninseminated cows were considered as cyclic [lactating cyclic (LC), $\mathrm{n}=8$; nonlactating cyclic (NLC), $\mathrm{n}$ $=5]$. Presynch was initiated with an i.m. injection of GnRH (100 $\mu \mathrm{g}$ of Cystorelin, Merial Ltd., Duluth, GA) at $44 \pm 3 \mathrm{~d}$ after parturition, followed $7 \mathrm{~d}$ later by an injection of $\mathrm{PGF}_{2 \alpha}(25 \mathrm{mg}$ of Lutalyse, Pfizer Animal Health, New York, NY). At 12 d after PGF $_{2 \alpha}$, the CIDRSynch protocol was initiated by administering 100 $\mu \mathrm{g}$ of $\mathrm{GnRH}$ and inserting an intravaginal progesterone insert (CIDR, Pfizer Animal Health) for $5 \mathrm{~d}$. Cows received an injection of $\mathrm{PGF}_{2 \alpha}$. (25 mg) at the time of CIDR removal and another $\mathrm{PGF}_{2 \alpha}$. $(25 \mathrm{mg}$ ) injection 12 $\mathrm{h}$ later. Then, GnRH $(100 \mu \mathrm{g})$ was injected $72 \mathrm{~h}$ after the first $\mathrm{PGF}_{2 \alpha}$ and cows were TAI twice (i.e., a.m. 


\section{Presynchronization}

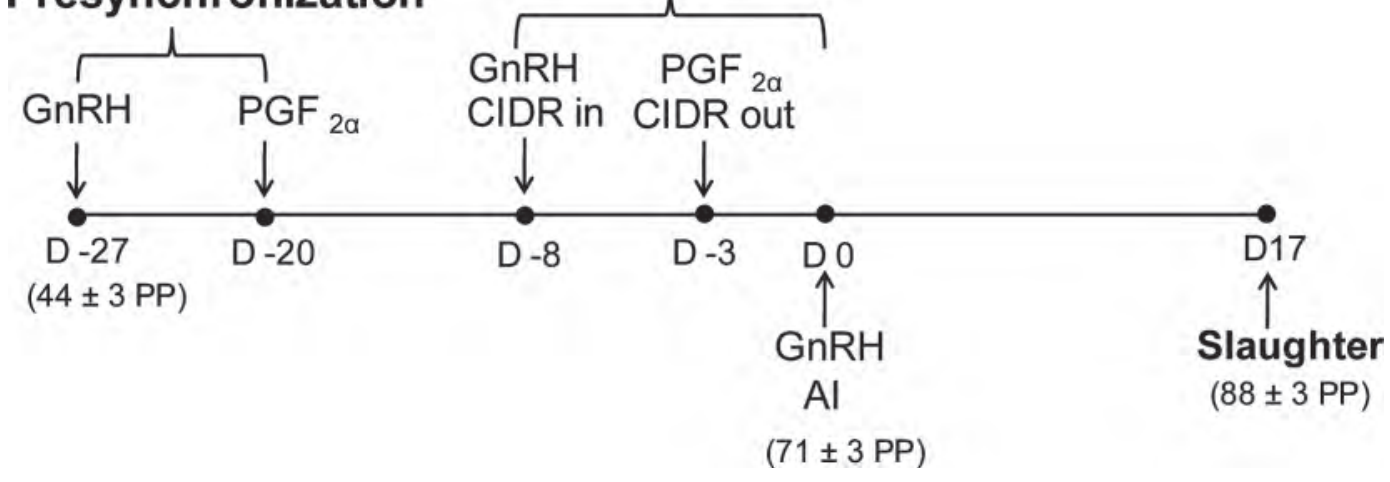

Figure 1. Experimental design. $\mathrm{PP}=$ days postpartum; CIDR $=$ controlled internal drug releasing containing progesterone; GnRH $=$ injection of gonadotropin releasing hormone; $\mathrm{PGF}_{2 \alpha}=$ prostaglandin $\mathrm{F}_{2 \alpha}$ injection; CIDRSynch = protocol for synchronization of ovulation.

and p.m.). On d 17 after GnRH and TAI, inseminated and noninseminated (i.e., cyclic) cows were slaughtered (Figure 1).

\section{Rectal Temperature, BW, BCS, and Ovarian Ultrasonography}

Rectal temperatures were collected thrice weekly using a digital thermometer (GLA Agricultural Electronics, San Luis Obispo, CA). The BW measurements were performed weekly, and BCS was measured every 14 d. Ovarian ultrasound (linear array $7.5-\mathrm{MHz}$ transrectal transducer, Aloka SSD-500, Aloka Co. Ltd., Wallingford, CT) examinations were performed weekly starting at $14 \pm 3 \mathrm{~d}$ after parturition until the day before slaughter. Presence, number, and size of CL and follicles were recorded.

\section{Concentration of Metabolites and Hormones in Plasma}

Blood samples used for measurement of metabolites and hormones were collected from all cows in both treatment groups thrice weekly from the day of parturition until the day of CIDR insertion and thrice weekly from the day of GnRH-TAI until the day of slaughter.

The samples were obtained from the coccygeal vessels into evacuated tubes containing EDTA (10-mL Vacutainer, Becton Dickinson, Franklin Lakes, NJ). Samples were placed on ice immediately after collection. Samples were centrifuged at $2,619 \times g$ for $30 \mathrm{~min}$ at $4^{\circ} \mathrm{C}$, and plasma was stored at $-20^{\circ} \mathrm{C}$. Concentrations of NEFA (NEFA-HR, Wako Diagnostics, Richmond, VA) and BHBA (Autokit 3-HB, Wako Diagnostics) were determined by using an enzymatic colorimetric assay. A Technicon Autoanalyzer (Technicon Instruments Corp., Chauncey, NY) was used to determine concentrations of BUN, using a modification of Coulombe and Favreau (1963) and Marsh et al. (1965), and plasma glucose, using a modification of Gochman and Schmitz (1972). Plasma concentrations of insulin were determined by using a double-antibody RIA (Malven et al., 1987; Badinga et al., 1991), and sensitivity of the assay was $1 \mathrm{ng} / \mathrm{mL}$. Total IGF-1 analysis of plasma was performed using a commercial ELISA kit (DSL10-2800 Nonextraction IGF-1, Diagnostic Systems Laboratories Inc., Webster, TX) following the manufacturer's instructions. Plasma concentrations of progesterone were determined by a solid-phase, no-extraction RIA (Coat-A-Count Progesterone, Diagnostic Products Corp., Los Angeles, CA). The standard curve dilution consisted of duplicated plain tubes used for total counts and nonspecific binding. A $100-\mu \mathrm{L}$ aliquot of increasing concentrations of calibrators $(0.1,0.25,0.5,1,2,5,10$, and $20 \mathrm{ng} / \mathrm{mL}$ ) was added to the tubes. The sensitivity of the assay was $0.1 \mathrm{ng} / \mathrm{mL}$, and the intraassay CV for samples of plasma on $\mathrm{d} 4(1.25 \mathrm{ng} / \mathrm{mL} \pm 0.04)$ and $\mathrm{d}$ $8(3.65 \mathrm{ng} / \mathrm{mL} \pm 0.16)$ of the cycle were 10 and $12.7 \%$, respectively.

\section{Tissue Collection}

All cows were slaughtered in the abattoir of the Department of Animal Sciences at the University of Florida. Reproductive tracts were collected within 10 min of slaughter. The uterine horn ipsilateral to the CL was cut along the antimesometrial border and the entire uterine horn was exposed. If the cow was inseminated, then the uterine horn was examined for presence of a conceptus. If present, the conceptus was collected, 
measured, weighed, and frozen in liquid nitrogen for subsequent RNA analyses. Endometrial tissue was dissected from the myometrium, and different sections of the intercaruncular endometrium were frozen in liquid nitrogen. Each ovary (i.e., CL-bearing and non-CL-bearing ovaries) was dissected from the uterus and weighed. The CL were removed from the ovary, weighed, and frozen in liquid nitrogen. After excluding cows that did not conceive in the TAI/pregnant groups (i.e., $2 \mathrm{~L}$ and $6 \mathrm{NL}$ ) and cows with pyometra (i.e., 1 L) and regressed CL (i.e., 1 NL), we utilized 7 LC (lactating cyclic), 8 lactating pregnant (LP), 4 NLC (nonlactating cyclic), and 6 nonlactating pregnant (NLP) cows for microarray analyses.

\section{RNA Extraction}

The RNA from conceptus and intercaruncular endometrial tissues was extracted using TRIzol reagent (Invitrogen Corp., Carlsbad, CA) according to instructions provided by the manufacturer. Samples were purified (PureLink Micro-to-Midi kit, Invitrogen Corp.), and RNA concentrations and purity were determined (Agilent 2100 Bioanalyzer, Agilent Technologies Inc., Santa Clara, CA). All samples were further processed for amplification and labeling and had a RNA integrity number $>7.5$, which is related to the ratio of $18 \mathrm{~S}$ and $28 \mathrm{~S}$ ribosomal subunits. Samples were placed in aliquots and stored at $-80^{\circ} \mathrm{C}$. Amplification and biotin labeling were performed with an initial $200 \mathrm{ng}$ of RNA by using MessageAmp III (Applied Biosystems Inc., Foster City, CA) according to the manufacturer's guidelines. Samples were then tested in the bioanalyzer for quality determination and subsequently submitted for fragmentation and hybridization in the bovine microarray.

\section{Conceptus and Endometrial Gene Expression}

The GeneChip Bovine Genome Array (Affymetrix Inc., Santa Clara, CA) used for conceptus and endometrial gene expression contains approximately 24,000 probe sets that represent over 23,000 bovine transcripts and includes approximately 19,000 UniGene clusters. The Affymetrix GeneChip uses 25-mer oligonucleotides to measure the abundance of mRNA transcripts, and each probe set contains 11 probe-pair replicates. Each probe is designed to hybridize to a specific sequence, and a mismatch probe that has one mismatched nucleotide allows for accurate quantitation and subtraction of background fluorescence and hybridization of nonspecific sequences. The specific probe and its mismatch constitute a probe pair and the probe set on the chip comprises 11 probe pairs for that bovine transcript. Hybridization controls are used to assess both chip quality and hybridization efficiency and are used to standardize signal intensity for the chip. The hybridization controls and labeling controls were consistent across the 13 conceptus arrays within each hybridization control (AFFXr2-P1-CRE-avg; AFFX-r2-Ec-bioD-avg; AFFX-r2-Ec-bioC-avg; AFFX-r2-Ec-bioB-avg) and labeling control (AFFX-r2-Bs-dap-avg; AFFX-r2-Bs-thravg; AFFX-r2-Bs-phe-avg; AFFX-r2-Bs-lys-avg) probe sets. Overall average expressions for hybridization control and labeling control were 1,152 and 7, respectively. Density plots indicated that arrays among conceptuses were homogeneous. The Box plots of the conceptus arrays before and after GeneChip Robust Multichip Analysis (GCRMA, Affymetrix Inc.) normalization were similar. Average expressions were as follows: GAPDH, 42,500; actin, 1,800; cyclophilin B, 16,000; glutathione S-transferase pi (GSTP1) , 7,000. Average expression of genes studied was 17,800. Raw expression values were normalized by the GCRMA ( $\log _{2}$-transformed). Values presented were untransformed and presented as least squares means and standard errors; the threshold detection level was 40 .

\section{Genes of Interest}

We evaluated correlations between $P A G$ family gene members, which are expressed exclusively by trophoblast cells, and a set of prostaglandin regulatory genes (i.e., prostaglandin synthases) characteristically expressed in the conceptus during early pregnancy.

\section{Statistical Analysis}

Temperature, BW, BCS, and metabolic and progesterone responses were analyzed using repeated-measures analyses of the mixed model procedure (PROC MIXED) of SAS (SAS/STAT, ver. 9.1, SAS Institute Inc., Cary, NC). This procedure applies methods based on the mixed model with special parametric structure on the covariance matrices. The data were tested to identify the covariance structure that provided the best fit for the data (Akaike's information criterion). Covariance structures tested included compound symmetry, autoregressive order 1, and unstructured; the covariance structure used was autoregressive order 1 . The model included the effects of treatment, day of measurement, and interaction of treatment by day of measurement, with cow nested within treatment as the random effect. Survival analysis using Cox proportional hazards regression (PROC PHREG) of SAS was performed to evaluate cyclicity of the 2 treatment 
groups. Homogeneity of regression analyses (Guilbault et al., 1985) for concentrations of progesterone in NL and L cyclic and pregnant cows were conducted using the PROC GLM procedure of SAS. Regression analyses were performed to determine the best-fit curves among treatments in relation to day of measurement. Linear, quadratic, and cubic curves were tested. All variables were analyzed with the main effects of treatment, day of measurement, cow within treatment, and the interaction of treatment by day of measurement. Cow nested within treatment was considered random.

Gene expression statistical tests were performed primarily using Bioconductor statistical software (http:// www.bioconductor.org/), which is an open source and development software packet for analysis of microarray throughput data based primarily on the $\mathrm{R}$ programming language (Gentleman et al., 2004). All array data were first preprocessed and normalized using the Affy package (Bolstad et al., 2003). Raw data were normalized by the GCRMA approach (Wu et al., 2004), and then the probe set's detection call was estimated by using the Wilcoxon signed rank-based algorithm. Probe sets that were absent in all study samples were removed from further analyses. For each gene represented on the microarray, a 2-way ANOVA was conducted to identify genes that were regulated differentially for lactation (NL and L), reproductive status (cyclic and pregnant), and the interaction of lactation and reproductive status. A linear modeling approach and the empirical Bayes statistics as implemented in the Limma package (Smyth, 2004) of the R software were used for differential expression analysis. Differentially expressed genes were then ranked by $P$-values, and genes with $P$-value $<0.05$ were considered as differentially expressed at a statistically significant level.

Conceptus expression of PAG11 gene was associated with other expressed genes: PTGES (prostaglandin E synthase), PTGES3 (prostaglandin E synthase 3, cytosolic), and PGH2S (prostaglandin endoperoxidase synthase 2) by correlation analyses, which were also used to determine correlations between different postpartum metabolites and hormones. PROC CORR of SAS was used to determine simple Pearson correlation coefficients. Standard partial correlation analyses were performed by multivariate ANOVA (MANOVA) using PROC GLM of SAS. The MANOVA was used to analyze the relationship of more than one dependent variable at a time and allowed for testing the effect of one independent variable on more than one dependent variable. The MANOVA detects differences in correlations among dependent variables when holding an independent variable constant.

\section{RESULTS}

\section{Breeding, Rectal Temperature, BW, BCS, and Milk Production}

The experiment had 35 cows presented for slaughter. Six of the 12 cows inseminated in the NL and 8 of 10 in the L group had a conceptus recovered at d 17 after AI. Moreover, NL and L groups had a total of 4 and 7 noninseminated (i.e., cyclic) cows, respectively.

Body weight averaged $509.7 \pm 13.2 \mathrm{~kg}$ for cows in the $\mathrm{L}$ group and $516.6 \pm 13.6 \mathrm{~kg}$ for cows in the NL group $(P>0.10)$. Mean BCS did not differ $(P>0.10)$ between groups and were $3.08 \pm 0.07$ and $3.18 \pm 0.07$ for L and NL, respectively. An overall decrease in BW of $42 \mathrm{~kg}$ occurred by $30 \mathrm{~d}$ postpartum with a recovery of $42 \mathrm{~kg}$ by $60 \mathrm{~d}$ postpartum. However, we found no statistical differences in postpartum day trends of either BW or BCS between NL and L groups. Cows in the $\mathrm{L}$ groups had higher mean rectal temperatures than cows in the NL group $\left(38.4 \pm 0.04>38.2 \pm 0.04^{\circ} \mathrm{C} ; P\right.$ $<0.01$ ). Average milk production in $\mathrm{L}$ cows was 24.6 $\pm 0.84 \mathrm{~kg}$. Mean milk production of LC cows was 25.0 $\pm 0.23 \mathrm{~kg}$ and ranged from $18.9 \pm 0.40$ to $32.0 \pm 0.43$ $\mathrm{kg}$. Cows in the LP group had mean milk production of $23.7 \pm 0.20 \mathrm{~kg}$, ranging from $17.2 \pm 0.37$ to $27.1 \pm 0.52$ $\mathrm{kg}$. The average milk fat and protein percentages were $3.44 \pm 0.24 \%$ and $2.98 \pm 0.04 \%$, respectively.

\section{Ovarian Ultrasonography, Blood Metabolites, and Progesterone}

The NL cows resumed estrous cycles earlier $(P<$ 0.04) than the $\mathrm{L}$ cows $(26.4 \pm 2.01$ vs. $34.7 \pm 3.09$ DIM; hazard ratio $=0.464)$. Moreover, $77.7 \%(\mathrm{n}=$ 14/18) of cows in the L group were cycling by 55 DIM compared with $100 \%(17 / 17)$ for the NL cows. Daily rate of resumption of cyclicity was $53.6 \%$ lower for $\mathrm{L}$ than for NL cows.

Mean concentrations of NEFA in plasma did not differ between treatments $(P>0.10)$ and were $207.5 \pm$ 23.91 and $247.2 \pm 24.75 \mathrm{mEq} / \mathrm{L}$ for $\mathrm{L}$ and NL cows, respectively (Figure 2A). Cows in L had greater $(P<$ $0.01)$ concentrations of BHBA (4.90 \pm 0.23 vs. $2.97 \pm$ $0.24 \mathrm{mg} / \mathrm{dL}$; Figure 2B) and BUN (11.64 \pm 0.32 vs. 6.5 $\pm 0.33 \mathrm{mg} / \mathrm{dL}$; Figure 3A) throughout the postpartum period compared with NL cows. Concentrations of glucose in plasma were lower $(P<0.01)$ for $\mathrm{L}$ compared with NL cows $(74.0 \pm 1.12$ vs. $79.9 \pm 1.17 \mathrm{mg} / \mathrm{dL}$; Figure 3B) throughout the postpartum period. Mean concentrations of insulin did not differ between NL and $\mathrm{L}(1.22 \pm 0.09$ vs. $1.29 \pm 0.07 \mathrm{ng} / \mathrm{mL}$; Figure $4 \mathrm{~A})$. 
Concentrations of IGF-1 were lower $(P<0.01)$ for $\mathrm{L}$ compared with NL cows $(140.5 \pm 5.95$ vs. $198.2 \pm 7.26$ $\mathrm{ng} / \mathrm{mL}$; Figure 4B), and higher $(P=0.02)$ for pregnant compared with cyclic cows $[191.0 \pm 6.37$ (LP and NLP) vs. $147.6 \pm 6.90 \mathrm{ng} / \mathrm{mL}$ (LC and NLC); Figure 4C]. The least squares means of each cow for the concentrations of metabolites, IGF-1, insulin, and progesterone in plasma during the postpartum period (i.e., through $75 \mathrm{~d}$ postpartum) were not correlated with expressions of various genes in the conceptus, when unadjusted or adjusted for treatments in the statistical model.

Results of regression analyses conducted to examine homogeneity of regression for third-order curves of progesterone in plasma, from d 0 ( $\mathrm{GnRH}$ injection or TAI) until d 17 (day of slaughter), indicated a lactation $\times$ day effect $(P<0.01)$. Concentrations of progesterone in the NL (NLC and NLP) group increased to approximately $7 \mathrm{ng} / \mathrm{mL}$ by d 17 (Figure $5 \mathrm{~A}$ ), and to $5.5 \mathrm{ng} /$
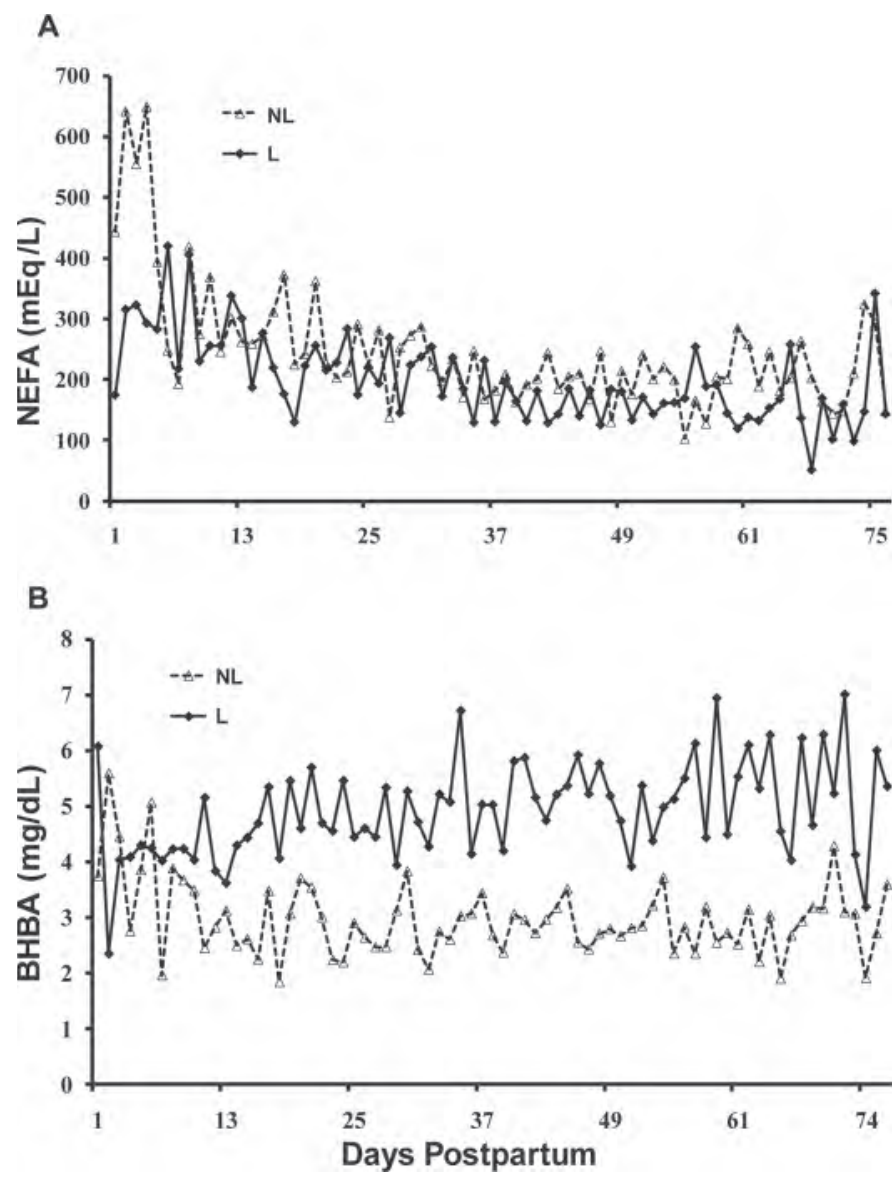

Figure 2. (A) Plasma concentrations of NEFA ( $\mathrm{mEq} / \mathrm{L})$ of lactating $(\mathrm{L})$ and nonlactating $(\mathrm{NL})$ cows; $\mathrm{LSM} \pm \mathrm{SEM}$ for $\mathrm{L}$ and NL cows were $207.5 \pm 23.91$ and $247.2 \pm 24.75 \mathrm{mEq} / \mathrm{L}$, respectively. (B) Plasma concentrations of BHBA $(\mathrm{mg} / \mathrm{dL})$ of L and NL cows; LSM \pm SEM for $\mathrm{L}$ and NL cows were $4.90 \pm 0.23$ and $2.97 \pm 0.24 \mathrm{mg} / \mathrm{dL}$, respectively.
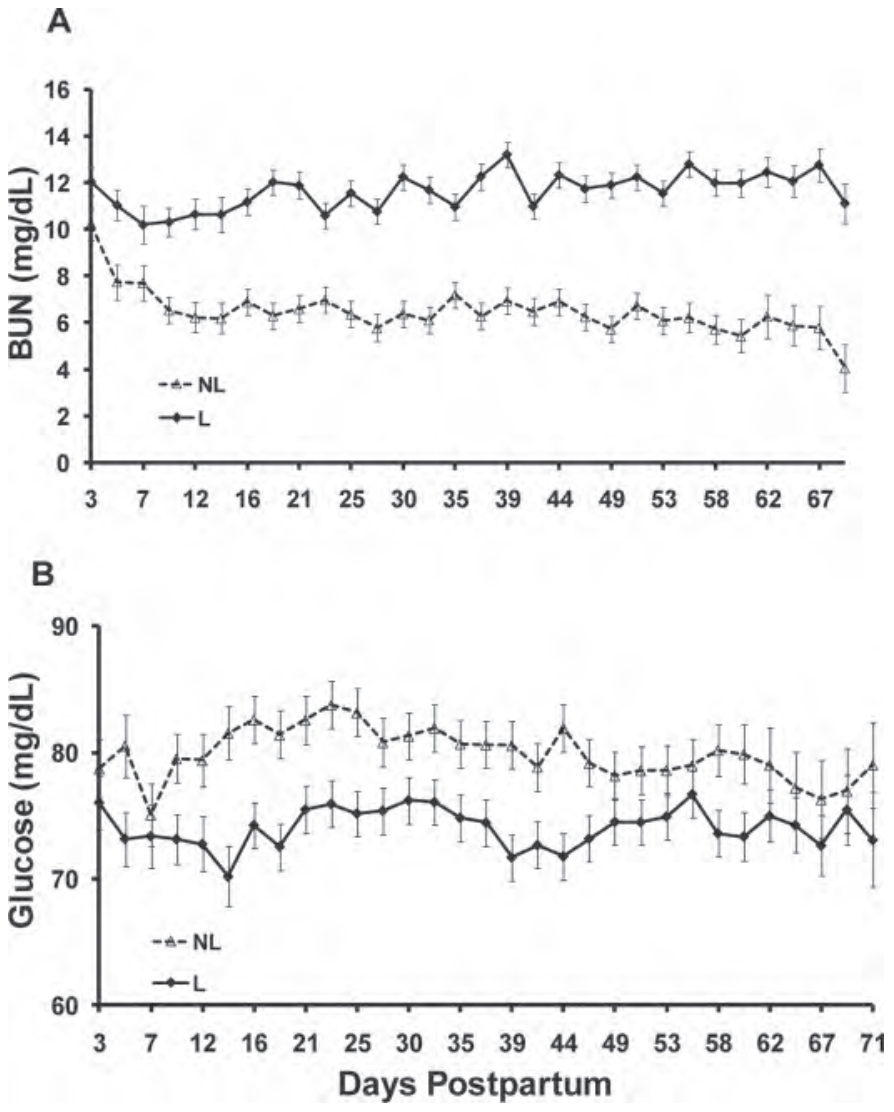

Figure 3. (A) Plasma concentrations of BUN (mg/dL) of lactating (L) and nonlactating (NL) cows; $\mathrm{LSM} \pm \mathrm{SEM}$ for $\mathrm{L}$ and NL cows were $11.64 \pm 0.32$ and $6.5 \pm 0.33 \mathrm{mg} / \mathrm{dL}$, respectively $(P<0.01)$. (B) Plasma concentrations of glucose $(\mathrm{mg} / \mathrm{dL})$ of $\mathrm{L}$ and NL cows; LSM \pm SEM for L and NL cows were $74.0 \pm 1.12$ and $79.9 \pm 1.17 \mathrm{mg} / \mathrm{dL}$, respectively $(P<0.01)$.

$\mathrm{mL}$ in the $\mathrm{L}$ (LC and LP) group during the same period (Figure 5B). Overall least squares means for plasma progesterone concentrations from GnRH injection or TAI (d 0) until d 17 was lower for L (LC and LP) cows compared with NL (NLC and NLP) cows $(3.04 \pm 0.10$ vs. $3.67 \pm 0.12 \mathrm{ng} / \mathrm{mL} ; P<0.002)$. The increase in concentrations of progesterone, reflected by the thirdorder curves, was less for LP cows compared with LC cows (Figure 5B). In contrast, we found no difference in the third-order progesterone curves between cyclic and pregnant cows of the NL group (Figure 5A).

An additional analysis was undertaken to examine plasma progesterone concentrations from d 0 to 8 after injection of $\mathrm{GnRH}$ to induce ovulation. A significant interaction of lactation, pregnancy, and day was detected for plasma progesterone $(P<0.03)$. Homogeneity of regression for linear increases in plasma progesterone indicated that the overall rate of increase was $0.44 \pm$ $0.04 \mathrm{ng} / \mathrm{mL}$ per day; Figure 6). The linear rates of increase in plasma progesterone concentrations for NLC 

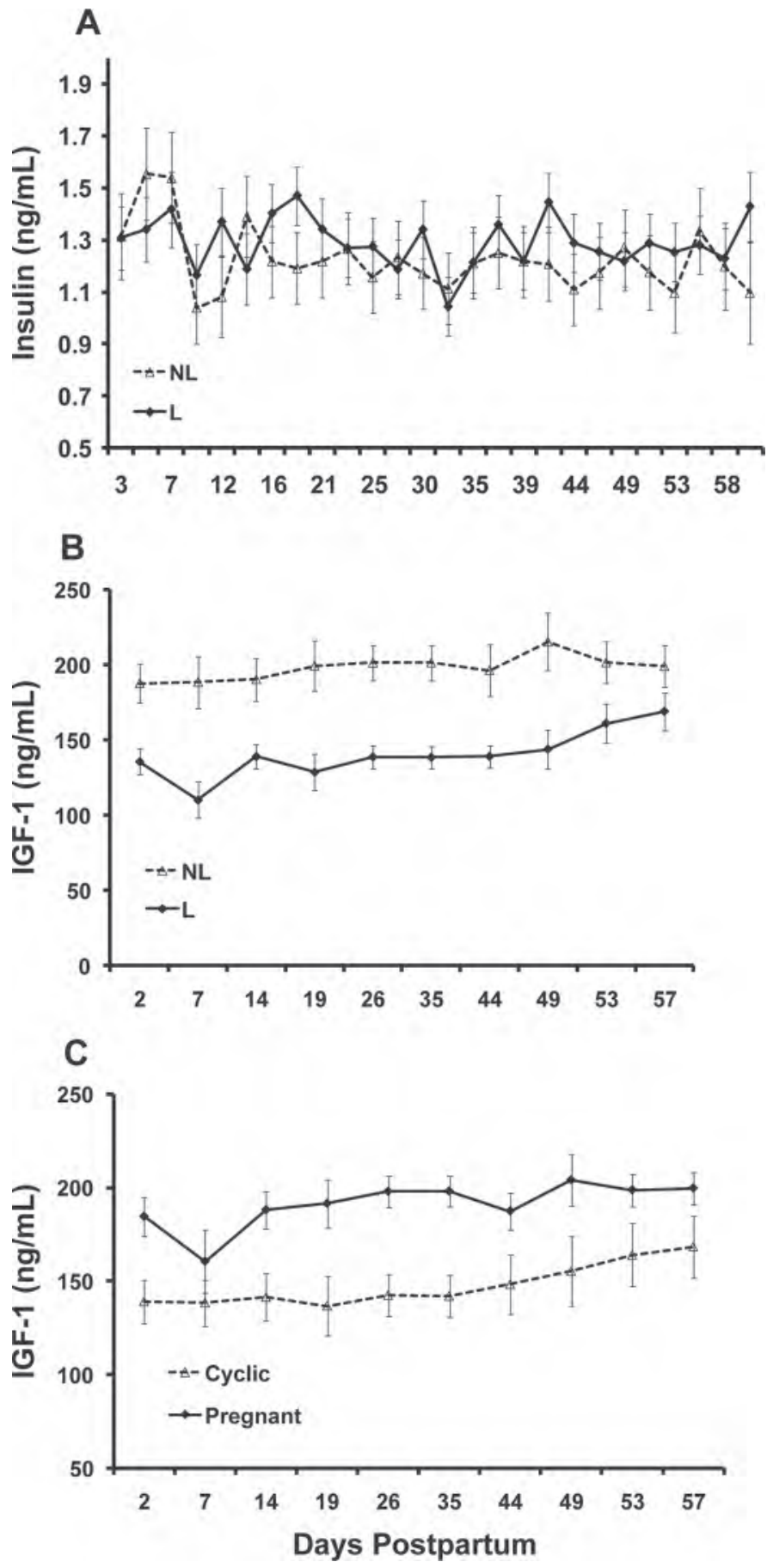

Figure 4. (A) Plasma concentrations of insulin $(\mathrm{ng} / \mathrm{mL})$ of lactating $(\mathrm{L})$ and nonlactating (NL) cows; $\mathrm{LSM} \pm \mathrm{SEM}$ for $\mathrm{L}$ and NL cows were $1.29 \pm 0.07$ and $1.22 \pm 0.09 \mathrm{ng} / \mathrm{mL}$, respectively. Plasma concentrations of IGF-1 (ng/mL) of L and NL cows (panel B) and cyclic (LC and NLC) and pregnant (LP and NLP) cows (panel C). The LSM \pm SEM for L and NL cows were $140.5 \pm 5.95$ and $198.2 \pm$ $7.26 \mathrm{ng} / \mathrm{mL}$, respectively; LSM \pm SEM for cyclic (LC and NLC) and pregnant (LP and NLP) cows were $147.6 \pm 6.90$ and $191.0 \pm 6.37 \mathrm{ng} /$ $\mathrm{mL}$, respectively.
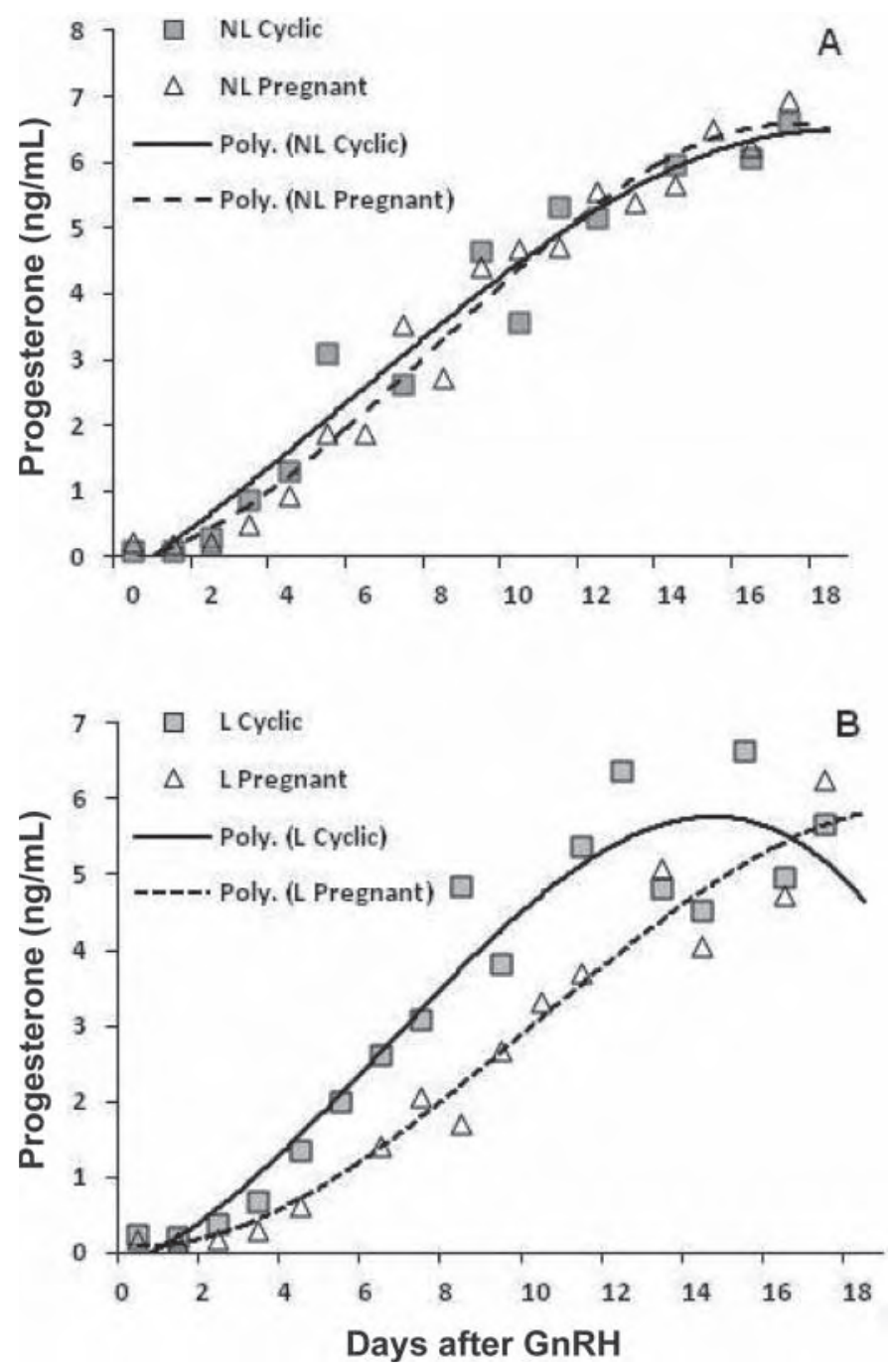

Figure 5. Third-order regression analyses of progesterone plasma concentrations $(\mathrm{ng} / \mathrm{mL})$ of $(\mathrm{A})$ nonlactating $(\mathrm{NL})$ and $(\mathrm{B})$ lactating (L) cyclic and pregnant cows from d $0(\mathrm{GnRH} /$ timed $\mathrm{AI})$ to d 17 (day of slaughter). Pooled standard error for a pregnancy status/lactation status cell at d 9 was \pm 1.34 . Poly. = third-order polynomial regression curve.

and NLP cows from d 0 to 8 were $0.48 \pm 0.05$ and 0.52 $\pm 0.04 \mathrm{ng} / \mathrm{mL}$ per day. In contrast, LC and LP cows had plasma progesterone increases of $0.45 \pm 0.04$ and $0.30 \pm 0.03 \mathrm{ng} / \mathrm{mL}$ per day from d 0 to 8 , respectively. The LP cows had a lower linear rate of plasma progesterone increase than LC, NLC, and NLP cows $(P<$ 0.01 ; lactation $\times$ pregnancy status $\times$ day interaction, $P<0.01)$.

\section{Reproductive Tract and Conceptus Characteristics}

Mean CL weight (Table 1 ) tended to be greater $(P$ $<0.10)$ for $\mathrm{L}$ than for NL cows $(6.39 \pm 0.37$ vs. 5.42 $\pm 0.44 \mathrm{~g})$. In contrast, mean CL weight did not differ 
Table 1. Least squares means $( \pm \mathrm{SE})$ for corpus luteum $(\mathrm{CL})$ weight, conceptus length, and conceptus weight from nonlactating and lactating cows during d 17 of estrous cycle and pregnancy

\begin{tabular}{|c|c|c|c|c|}
\hline \multirow[b]{2}{*}{ Item } & \multicolumn{2}{|c|}{ Nonlactating } & \multicolumn{2}{|c|}{ Lactating } \\
\hline & Cyclic $(\mathrm{n}=4)$ & Pregnant $(\mathrm{n}=6)$ & Cyclic $(\mathrm{n}=7)$ & Pregnant $(\mathrm{n}=8)$ \\
\hline $\begin{array}{l}\text { CL weight }^{1}(\mathrm{~g}) \\
\text { Conceptus length }(\mathrm{cm}) \\
\text { Conceptus weight }(\mathrm{mg})\end{array}$ & $4.95 \pm 0.66$ & $\begin{array}{c}5.81 \pm 0.60 \\
20.0 \pm 7.17 \\
34.75 \pm 16.04\end{array}$ & $6.15 \pm 0.56$ & $\begin{array}{l}6.60 \pm 0.52 \\
25.1 \pm 5.07 \\
60.0 \pm 11.91\end{array}$ \\
\hline
\end{tabular}

${ }^{1}$ Nonlactating versus lactating: $P<0.10$.

between cyclic and pregnant cows as a main effect $(5.65$ \pm 0.41 vs. $6.26 \pm 0.41 \mathrm{~g})$, and the interaction between lactation and pregnancy status was not significant. Conceptus length and weight did not differ between pregnant cows of the NL and L groups (Table 1).

\section{PAG Expression in Conceptus}

The PAG family gene member most abundantly expressed by d 17 conceptuses was PAG11 (expression level $=53,831 \pm 2,620)$. All conceptuses $(\mathrm{n}=13)$ expressed PAG2, PAG8, PAG11, and PAG12 (Table 2). The most highly expressed $P A G$ genes in all conceptuses (i.e., PAG11 and PAG2) were also expressed in the underlying endometrium in some cows. Additional PAG family genes were expressed by some conceptuses: PAG1 (n=1), PAG7 (n=3), PAG9 (n=1), PAG10 $(\mathrm{n}=1), P A G 17(\mathrm{n}=2), P A G 18(\mathrm{n}=1), P A G 20(\mathrm{n}=$ 1), and PAG21 ( $\mathrm{n}=5)$.

Prostaglandin-related expression of genes in the conceptus was not affected by lactation (Table 3). Simple

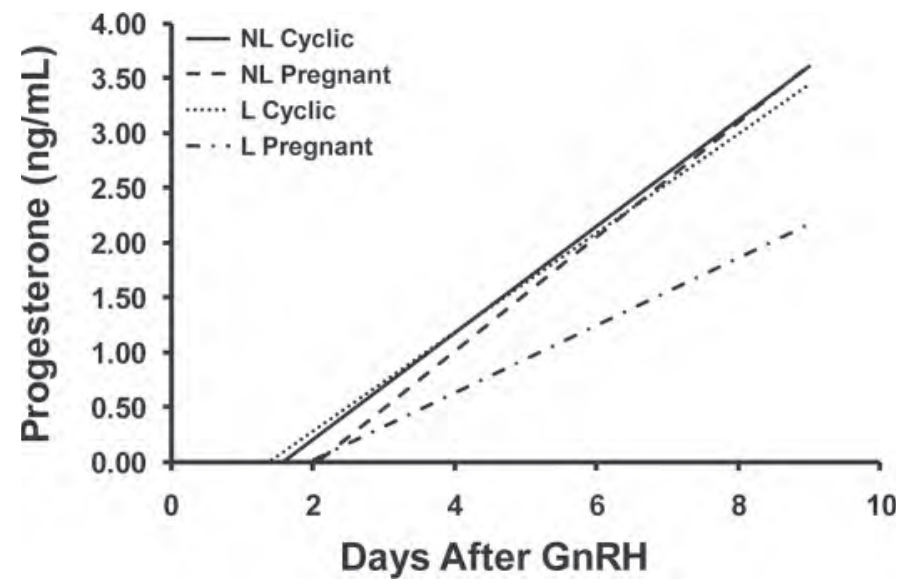

Figure 6. Linear regression analyses of progesterone plasma concentrations $(\mathrm{ng} / \mathrm{mL})$ of nonlactating $(\mathrm{NL})$ and lactating $(\mathrm{L})$ cyclic and pregnant cows from d $0(\mathrm{GnRH} /$ timed $\mathrm{AI})$ to $\mathrm{d} 8$ before slaughter. The rates of increase in plasma progesterone concentrations for NL cyclic and pregnant cows from d 0 to 8 were 0.48 and $0.52 \mathrm{ng} / \mathrm{mL}$ per day, respectively. The $\mathrm{L}$ cyclic and pregnant cows had plasma progesterone increases of 0.45 and $0.30 \mathrm{ng} / \mathrm{mL}$ per day from $\mathrm{d} 0$ to 8 . correlation (r) analyses detected associations of PAG11 expression with expression levels of several other genes in the conceptus (Figure 7): PGH2S ( $\mathrm{r}=0.87 ; P<$ $0.01)$, PTGES ( $\mathrm{r}=0.76 ; P<0.01)$, and PTGES3 ( $\mathrm{r}$ $=0.69 ; P<0.02)$. When standard partial correlations (pr) were calculated while $P G H 2 S$ was held constant, we observed a decrease in the correlations of PAG11 with PTGES (pr $=0.50 ; P<0.09)$ and PTGES3 (pr $=0.17 ; P<0.59$ ). Moreover, standard partial correlations between $P A G 11$ and $P G H 2 S$ remained high when PTGES $(\mathrm{pr}=0.76 ; P<0.01)$ and PTGES3 $(\mathrm{pr}=0.74$; $P<0.01$ ) were held constant (Figure 7 ).

\section{DISCUSSION}

The present experiment evaluated lactation effects on postpartum metabolic changes, ovarian activity, and subsequent endometrial and conceptus gene expression at d 17 of the cycle and pregnancy. This was accomplished in first-calf heifers that underwent lactation or were dried off at parturition and fed to meet their respective energy requirements. The effects of age and culling were not confounding factors, and the major difference between treatment groups was lactation itself. Indeed, lactation delayed cyclicity and distinct metabolic differences were detected due to lactational status.

Table 2. Least squares means $( \pm \mathrm{SE})$ for conceptus and endometrial expression of pregnancy-associated glycoprotein (PAG) genes at d 17 of pregnancy

\begin{tabular}{lrrr}
\hline & \multicolumn{3}{c}{ Gene expression level ${ }^{1}$} \\
\cline { 2 - 4 } Gene & $\begin{array}{c}\text { Conceptus } \\
(\mathrm{n}=13)\end{array}$ & $\begin{array}{c}\text { Endometrium: } \\
\text { cyclic cows }\end{array}$ & $\begin{array}{r}\text { Endometrium: } \\
\text { pregnant cows }\end{array}$ \\
\hline PAG2 & $28,818 \pm 1,435$ & $\mathrm{UD}^{2}(0 / 11)$ & $53 \pm 36(4 / 14)$ \\
PAG8 & $10,352 \pm 1,892$ & UD $(0 / 11)$ & UD $(0 / 14)$ \\
PAG11 & $53,831 \pm 2,620$ & UD $(0 / 11)$ & $84 \pm 39(7 / 14)$ \\
PAG12 & $9,187 \pm 1,170$ & UD $(0 / 11)$ & UD $(0 / 14)$ \\
\hline
\end{tabular}

${ }^{1}$ Raw expression values were normalized by the GeneChip Robust Multichip Analysis ( $\log _{2}$-transformed; Affymetrix Inc., Santa Clara, $\mathrm{CA}$ ). Values presented are untransformed and the threshold detection level is 40 .

${ }^{2}$ Undetected. 
Table 3. Least squares means $( \pm \mathrm{SE})$ for expression level ${ }^{1}$ of selected genes in conceptus at d 17 of pregnancy of lactating and nonlactating cows

\begin{tabular}{lccc}
\hline Gene $^{2}$ & Lactating & Nonlactating & $\begin{array}{c}\text { Lactation } \\
P \text {-value }\end{array}$ \\
\hline PAG11 & $55,426 \pm 3,396$ & $51,281 \pm 4,296$ & 0.38 \\
PTGES & $1,210 \pm 420$ & $1,409 \pm 663$ & 0.55 \\
PTGES3 & $8,716 \pm 292$ & $8,835 \pm 421$ & 0.84 \\
PGH2S & $13,641 \pm 379$ & $12,285 \pm 1,527$ & 0.25 \\
\hline
\end{tabular}

${ }^{1}$ Raw expression values were normalized by the GeneChip Robust Multichip Analysis ( $\log _{2}$-transformed; Affymetrix Inc., Santa Clara, $\mathrm{CA})$. Values presented are untransformed and the threshold detection level is 40 .

${ }^{2}$ PAG11 = pregnancy-associated glycoprotein $11 ;$ PTGES $=$ prostaglandin E synthase; PTGES3 = prostaglandin E synthase 3 (cytosolic); $P G H 2 S=$ prostaglandin endoperoxidase synthase 2 .

Metabolic responses indicated by concentrations of NEFA, BHBA, BUN glucose, insulin, and IGF-1 in plasma indicated that $\mathrm{L}$ cows underwent metabolic changes associated with homeorhetic processes in response to lactogenesis and galactopoiesis. The alterations in metabolites reflect mobilization of lipids and proteins during a period of negative energy balance postpartum. Overall, cows experienced a temporal 42$\mathrm{kg}$ decline and restoration of BW during the postpartum period. Metabolic changes related to lactational status were observed even though we observed no differences in BW and BCS between L and NL cows. The lack of an effect of lactation on concentrations of NEFA despite an increase in plasma BHBA concentrations could be explained by the relatively moderate production in $\mathrm{L}$ cows and by the differences in the 2 treatment diets. Cows in the L group produced around $24 \mathrm{~kg}$ of milk, which probably minimized the intensity and length of lipid mobilization soon after calving and could explain the absence of an effect on NEFA concentrations compared with the NL group. The greater concentration of BHBA in $\mathrm{L}$ cows is likely a consequence of access to a diet expected to generate more VFA in the rumen, including butyric acid, which could then be transferred to the peripheral circulation. In addition, L cows had higher BUN concentrations compared with NL cows, perhaps because of the greater amount of $\mathrm{CP}$ in the diet offered to the L treatment group. Furthermore, L cows had lower plasma concentrations of glucose, likely due to greater glucose utilization by the mammary gland compared with that in NL cows. However, the difference in steady-state concentrations of glucose did not alter concentrations of insulin postpartum, but was correlated positively with concentrations of IGF-1.

Low availability of energy contributes to delayed resumption of ovulation postpartum by suppressing $\mathrm{LH}$ secretion and reducing ovarian responsiveness to LH stimulation (Butler, 2003). Moreover, reductions in concentrations of metabolic hormones such as insulin and IGF-1 also influence follicular development and peripartum ovulation. Both of these molecules affect function of granulosa cells (Sudo et al., 2007; Shimizu et al., 2008). Cows that experience an early postpartum increase in IGF-1 concentrations in plasma have enhanced ovarian follicular development coupled with increased estradiol secretion (Beam and Butler, 1997, 1999) and an earlier occurrence of ovulations (Thatcher et al., 1996). In the present study, lactation delayed resumption of postpartum ovulation, which could be explained by the lower concentrations of IGF-1 and glucose in L cows.

Furthermore, concentration of IGF-1 differed between the subsequent cyclic and pregnant cows. The reason for the greater concentrations of IGF-1 in plasma of pregnant cows is unknown and requires further investigation. Perhaps, of the cows enrolled to be TAI, those with a better metabolic status had greater plasma concentrations of IGF-1 and were more likely to conceive regardless of lactational state.

The L cows had lower plasma concentrations of progesterone and greater CL weight compared with NL cows, a result that is in agreement with Sartori et al. (2002). Cows in the NL group had a greater rate of increase in plasma progesterone concentrations compared with $\mathrm{L}$ cows from d 0 to 8 of the study, which coincides with the period of early CL development before slaughter. Sartori et al. (2002, 2004) also found larger follicles and CL and lower concentrations of estradiol and progesterone in lactating cows compared with

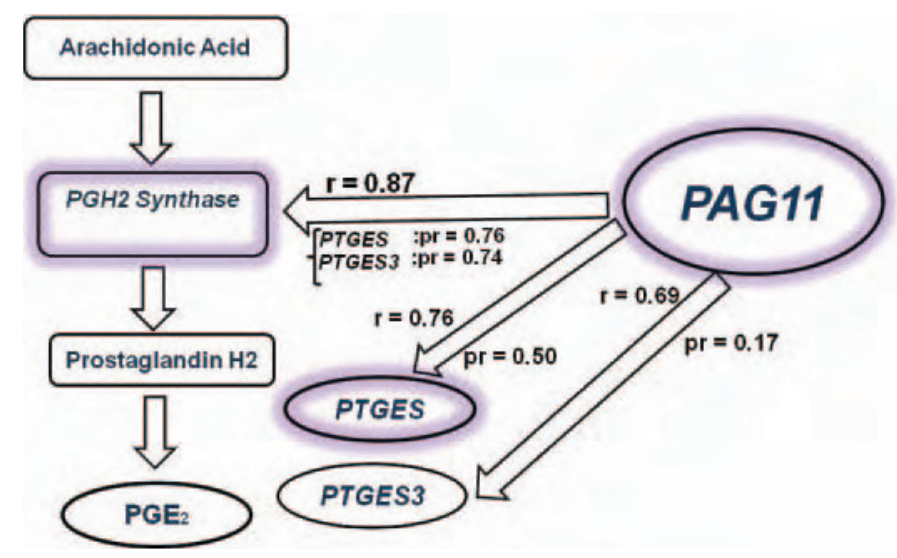

Figure 7. Simple (r) and standard partial (pr) correlations of conceptus expression of PAG11 (pregnancy-associated glycoprotein 11) with conceptus expression of prostaglandin regulatory genes PGH2S (prostaglandin endoperoxidase synthase 2), PTGES (prostaglandin E synthase), and PTGES3 (prostaglandin E synthase 3, cytosolic). Grey (purple) shadow represents genes that were correlated with PAG11 in both simple and partial correlation analyses. Color version available in the online PDF. 
heifers, and in lactating cows compared with nonlactating cows. This effect can be attributed to possibly greater steroid metabolism within the liver in lactating dairy cows (Sangsritavong et al., 2002). Interestingly, $\mathrm{L}$ pregnant cows had a smaller increase in plasma progesterone concentrations compared with $\mathrm{L}$ cyclic cows. In contrast, the progesterone curves between cyclic and pregnant cows of the NL group did not differ.

In the present study, microarray analysis detected lactation, pregnancy, and lactation $\times$ pregnancy interaction effects on d 17 endometrial expression that are described in the companion paper (Cerri et al., 2012). Although several studies have documented the measurement of plasma PAG concentrations as an alternative tool for early pregnancy diagnosis (Humblot et al., 1988; Zoli et al., 1992; Green et al., 2005; Silva et al., 2007), the functional role of these molecules remains to be determined. Different $P A G$ family genes were identified in conceptuses and endometrial tissues at d 17 of pregnancy. The $P A G$ genes are thought to regulate a large family of placenta-expressed proteins (Green et al., 2000; Hughes et al., 2000). Limited expression of PAG2 and PAG11 genes in endometrial tissue was detected in some pregnant cows at d 17 of pregnancy. This most likely reflects initiation of $P A G$ family expression within cellular components associated with temporal cellular differentiation, attachment, and placentogenesis. Ishiwata et al. (2003) described the endometrial presence of $P A G$ family genes at $\mathrm{d} 30$ of gestation with a 2-fold expression increase $30 \mathrm{~d}$ later, which reinforces the importance of PAG associated with placentogenesis and uterine reorganization at those stages. The findings of the current study may reflect the presence of trophoblast cells in the endometrium tissue at d 17 due to the intimate relationship between the trophectoderm and the endometrium at this time, as well as initial migration of binucleate cells from the trophoblast to the endometrium (Igwebuike, 2006).

All conceptuses readily expressed PAG2, PAG8, $P A G 11$, and PAG12, which are all members of the ancient PAG group that are expressed throughout the trophoblast by mononucleated and binucleated cells (Green et al., 2000). Moreover, other PAG, both ancient (PAG10) and modern (i.e., expressed in binucleate cells only: PAG1, PAG7, PAG9, PAG17, PAG18, PAG20, and $P A G 21)$, were expressed by some of the conceptuses. Simple and partial correlation analyses between readily expressed PAG11 gene in the conceptus at $\mathrm{d} 17$ of pregnancy and various candidate genes of interest were undertaken. Correlation analyses were conducted to identify associations that might be important functionally for pregnancy and to provide a basis for future studies to identify the possible function(s) of $P A G$ genes. The $P A G$ most highly expressed in the conceptus at d 17 of pregnancy was $P A G 11$ and correlation analysis was performed on expression values for this gene to gain insight into regulation and function. Different possible functions of $P A G$ genes may be related to the diverse localization of the ancient and modern $P A G$ groups. Ancient $P A G$ genes, mainly expressed at the microvillar junctions of the fetal-maternal interface, may be involved in binding together the fetal maternal surfaces or in establishing an immunological barrier. In contrast, the expression of modern $P A G$ genes (i.e., exclusively expressed in trophoblast binucleated cells) occurs mainly in the developing maternal villi of the placentomes, which are ideally positioned to manipulate the maternal immune system (Wooding et al., 2005).

Conceptus gene expression of PAG11 was correlated positively with that of PGH2S, PTGES, and PTGES3 of the conceptus (Figure 7). However, standard partial correlation analyses holding $P G H 2$ synthase as a constant showed a decrease in the correlations between PAG11 with PTGES and PTGES3, suggesting that PAG11 may primarily affect upstream expression of $P G H 2$ synthase, that then leads to downstream regulation of $P G E S$ and PGES3. The possible role of PAG protein in regulation of the prostaglandin cascade is supported by a series of experimental in vivo and in vitro approaches. Administration of PAG1 or PSPB to cultured bovine luteal cells promoted the release of prostaglandin $\mathrm{E}_{2}$ $\left(\mathbf{P G E}_{2}\right.$; Del Vecchio et al., 1996; Weems et al., 1998a) and increased progesterone secretion (Del Vecchio et al., 1996; Weems et al., 1998b). In contrast, Del Vecchio et al. (1995) reported no increase in progesterone from luteal cells treated with PSPB. Administration of PSPB to bovine cultured endometrial explants of $d$ 16 of the estrous cycle increased secretion of $\mathrm{PGE}_{2}$ and $\mathrm{PGF}_{2 \alpha}$ (Del Vecchio et al., 1990). In another study, 90-d pregnant ewes were ovariectomized, and serial blood samples were collected over a 7-d period for analyses of progesterone, estradiol-17 $\beta, \mathrm{PGE}_{2}, \mathrm{PGF}_{2 \alpha}$, and PSPB. Plasma PSPB and estradiol-17 $\beta$ concentrations were increased in ovariectomized ewes compared with intact ewes. Increased concentrations of PSBP were preceded by an increase in estradiol. In vitro studies with placenta slices of the same ovariectomized ewes collected $7 \mathrm{~d}$ after laparotomy revealed an increase in progesterone, $\mathrm{PGE}_{2}$, estradiol-17 $\beta$, and PSPB secretions compared with secretion by placenta of intact ewes. The authors concluded that estradiol might regulate PSPB secretion to stimulate placental $\mathrm{PGE}_{2}$ secretion that in turn sustains placental secretion of progesterone in sheep (Weems et al., 1999). The dynamics of progesterone secretion during early pregnancy in cattle is largely sustained by the CL, not by the placenta. 


\section{CONCLUSIONS}

Lactation altered metabolic status, even though BW and BCS were the same between L and NL cows. Lactation delayed initiation of cyclicity and decreased concentrations of progesterone in pregnant L cows during a programmed period following an induced ovulation. Novel findings are that early expression of $P A G$ genes within the conceptus of a pregnant cow and its association with the prostaglandin cascade network infer a possible role of $P A G$ in prostaglandin biosynthesis, pregnancy maintenance, and conceptus development. This physiological model provides a platform for examining lactation effects on subsequent endometrial and conceptus transcriptomes.

\section{REFERENCES}

Austin, K. J., C. P. King, J. E. Vierk, R. G. Sasser, and T. R. Hansen. 1999. Pregnancy-specific protein B induces release of an alpha chemokine in bovine endometrium. Endocrinology 140:542-545.

Badinga, L., R. J. Collier, W. W. Thatcher, C. J. Wilcox, H. H. Head, and F. W. Bazer. 1991. Ontogeny of hepatic bovine growth hormone receptors in cattle. J. Anim. Sci. 69:1925-1934.

Bauersachs, S., S. E. Ulbrich, K. Gross, S. E. Schmidt, H. H. Meyer, H. Wenigerkind, M. Vermehren, F. Sinowatz, H. Blum, and E. Wolf. 2006. Embryo induced transcriptome changes in bovine endometrium reveal species-specific and common molecular markers of uterine receptivity. Reproduction 132:319-331.

Beam, S. W., and W. R. Butler. 1997. Energy balance and ovarian follicle development prior to the first ovulation postpartum in dairy cows receiving three levels of dietary fat. Biol. Reprod. $56: 133-142$.

Beam, S. W., and W. R. Butler. 1999. Effects of energy balance on follicular development and first ovulation in postpartum dairy cows. J. Reprod. Fertil. Suppl. 54:411-424.

Bolstad, B. M., R. A. Irizarry, M. Astrand, and T. P. Speed. 2003. A comparison of normalization methods for high density oligonucleotide array data based on variance and bias. Bioinformatics 19:185-193.

Butler, J. E., W. C. Hamilton, R. G. Sasser, C. A. Ruder, G. M. Hass, and R. J. Williams. 1982. Detection and partial characterization of two bovine pregnancy-specific proteins. Biol. Reprod. 26:925-933.

Butler, W. R. 2003. Energy balance relationships with follicular development, ovulation and fertility in postpartum dairy cows. Livest. Prod. Sci. 83:211-218.

Butler, W. R. 2005. Relationships of negative energy balance with fertility. Adv. Dairy Technol. 17:35-46.

Cerri, R. L. A., I. M. Thompson, I. H. Kim, A. D. Ealy, P. J. Hansen, C. R. Staples, J. L. Li, J. E. P. Santos, and W. W. Thatcher. 2012. Effects of lactation and pregnancy on gene expression of endometrium of Holstein cows at day 17 of the estrous cycle or pregnancy. J. Dairy Sci. 95:5657-5675. http://dx.doi.org/10.3168/ jds.2011-5114.

Coulombe, J. J., and L. Favreau. 1963. A new simple semimicro method for colorimetric determination of urea. Clin. Chem. 9:102-108.

Del Vecchio, R. P., R. G. Sasser, and R. D. Randel. 1990. Effect of pregnancy-specific protein B on prostaglandin F2 alpha and prostaglandin E2 release by day 16-perifused bovine endometrial tissue. Prostaglandins 40:271-282.

Del Vecchio, R. P., W. D. Sutherland, and R. G. Sasser. 1995. Prostaglandin F2 alpha, progesterone and oxytocin production by cultured bovine luteal cells treated with prostaglandin E2 and pregnancy-specific protein B. Prostaglandins 50:137-150.
Del Vecchio, R. P., W. D. Sutherland, and R. G. Sasser. 1996. Bovine luteal cell production in vitro of prostaglandin E2, oxytocin and progesterone in response to pregnancy-specific protein B and prostaglandin F2 alpha. J. Reprod. Fertil. 107:131-136.

Dosogne, H., C. Burvenich, A. E. Freeman, M. E. Kehrli, J. C. Detilleux, J. Sulon, J. F. Beckers, and D. Hoeben. 1999. Pregnancyassociated glycoprotein and decreased polymorphonuclear leukocyte function in early post-partum dairy cows. Vet. Immunol. Immunopathol. 67:47-54.

Forde, N., T. E. Spencer, F. W. Bazer, G. Song, J. F. Roche, and P. Lonergan. 2010. Effect of pregnancy and progesterone concentration on expression of genes encoding for transporters or secreted proteins in the bovine endometrium. Physiol. Genomics 41:53-62.

Gentleman, R. C., V. J. Carey, D. M. Bates, B. Bolstad, M. Dettling, S. Dudoit, B. Ellis, L. Gautier, Y. Ge, J. Gentry, K. Hornik, T. Hothorn, W. Huber, S. Iacus, R. Irizarry, F. Leisch, C. Li, M. Maechler, A. J. Rossini, G. Sawitzki, C. Smith, G. Smyth, L. Tierney, J. Y. H. Yang, and J. Zhang. 2004. Bioconductor: Open software development for computational biology and bioinformatics. Genome Biol. 5:R80.

Gochman, N., and J. M. Schmitz. 1972. Application of a new peroxide indicator reaction to the specific, automated determination of glucose with glucose oxidase. Clin. Chem. 18:943-950.

Green, J. A., T. E. Parks, M. P. Avalle, B. P. Telugu, A. L. McLain, A. J. Peterson, W. McMillan, N. Mathialagan, R. R. Hook, S. Xie, and R. M. Roberts. 2005. The establishment of an ELISA for the detection of pregnancy-associated glycoproteins (PAGs) in the serum of pregnant cows and heifers. Theriogenology 63:1481-1503.

Green, J. A., S. Xie, X. Quan, B. Bao, X. Gan, N. Mathialagan, J. F. Beckers, and R. M. Roberts. 2000. Pregnancy-associated bovine and ovine glycoproteins exhibit spatially and temporally distinct expression patterns during pregnancy. Biol. Reprod. 62:16241631.

Guilbault, L. A., W. W. Thatcher, R. J. Collier, and C. J. Wilcox. 1985. Periparturient endocrine changes of conceptus and maternal units in Holstein heifers bearing genetically different service sires. J. Anim. Sci. 61:1505-1515.

Hoeben, D., C. Burvenich, A. M. Massart-Leën, M. Lenjou, G. Nijs, D. V. Bockstaele, and J. F. Beckers. 1999. In vitro effect of ketone bodies, glucocorticosteroids and bovine pregnancy-associated glycoprotein on cultures of bone marrow progenitor cells of cows and calves. Vet. Immunol. Immunopathol. 68:229-240.

Hughes, A. L., J. A. Green, J. M. Garbayo, and R. M. Roberts. 2000. Adaptive diversification within a large family of recently duplicated, placentally expressed genes. Proc. Natl. Acad. Sci. USA 97:3319-3323.

Humblot, P., S. Camous, J. Martal, J. Charlery, N. Jeanquyot, M. Thibierland, and G. Sasser. 1988. Diagnosis of pregnancy by radioimmunoassay of pregnancy-specific protein in the plasma of dairy cows. Theriogenology 30:257-267.

Igwebuike, U. M. 2006. Trophoblast cells of ruminant placentas-A minireview. Anim. Reprod. Sci. 93:185-198.

Ishiwata, H., S. Katsuma, K. Kizaki, O. V. Patel, H. Nakano, T. Takahashi, K. Imai, A. Hirasawa, S. Shiojima, H. Ikawa, Y. Suzuki, G. Tsujimoto, Y. Izaike, J. Todoroki, and K. Hashizume. 2003. Characterization of gene expression profiles in early bovine pregnancy using a custom cDNA microarray. Mol. Reprod. Dev. 65:9-18.

Kindahl, H., B. Kornmatitsuk, K. Königsson, and H. Gustafsson. 2002. Endocrine changes in late bovine pregnancy with special emphasis on fetal well-being. Domest. Anim. Endocrinol. 23:321-328.

Malven, P. V., H. H. Head, R. J. Collier, and F. C. Buonomo. 1987. Periparturient changes in secretion and mammary uptake of insulin and in concentrations of insulin and insulin-like growth factors in milk of dairy cows. J. Dairy Sci. 70:2254-2265.

Marsh, W. H., B. Fingerhut, and H. Miller. 1965. Automated and manual direct methods for the determination of blood urea. Clin. Chem. 11:624-627.

Mialon, M. M., G. Renand, S. Camous, J. Martal, and F. Ménissier. 1994. Detection of pregnancy by radioimmunoassay of a pregnancy serum protein (PSP60) in cattle. Reprod. Nutr. Dev. 34:65-72. 
Patel, O. V., I. Domeki, N. Sasaki, T. Takahashi, M. Hirako, R. G. Sasser, and P. Humblot. 1995. Effect of fetal mass, number and stage of gestation on pregnancy-specific protein B concentrations in the bovine. Theriogenology 44:827-833.

Sangsritavong, S., D. K. Combs, R. Sartori, L. E. Armentano, and M. C. Wiltbank. 2002. High feed intake increases liver blood flow and metabolism of progesterone and estradiol-17 $\beta$ in dairy cattle. J. Dairy Sci. 85:2831-2842.

Santos, J. E. P., W. W. Thatcher, R. C. Chebel, R. L. A. Cerri, and K. N. Galvão. 2004. The effect of embryonic death rates in cattle on the efficacy of estrus synchronization programs. Anim. Reprod. Sci. $82-83: 513-535$.

Sartori, R., J. M. Haughian, R. D. Shaver, G. J. M. Rosa, and M. C. Wiltbank. 2004. Comparison of ovarian function and circulating steroids in estrous cycles of Holstein heifers and lactating cows. J Dairy Sci. 87:905-920.

Sartori, R., R. Sartor-Bergfelt, S. A. Mertens, J. N. Guenther, J. J. Parrish, and M. C. Wiltbank. 2002. Fertilization and early embryonic development in heifers and lactating cows in summer and lactating and dry cows in winter. J. Dairy Sci. 85:2803-2812.

Sasser, R. G., C. A. Ruder, K. A. Ivani, J. E. Butler, and W. C. Hamilton. 1986. Detection of pregnancy by radioimmunoassay of a novel pregnancy-specific protein in serum of cows and a profile of serum concentrations during gestation. Biol. Reprod. 35:936-942.

Shimizu, T., C. Murayama, N. Sudo, C. Kawashima, M. Tetsuka, and A. Miyamoto. 2008. Involvement of insulin and growth hormone (GH) during follicular development in the bovine ovary. Anim. Reprod. Sci. 106:143-152.

Silva, E., R. A. Sterry, D. Kolb, N. Mathialagan, M. F. McGrath, J. M. Ballam, and P. M. Fricke. 2007. Accuracy of a pregnancyassociated glycoprotein ELISA to determine pregnancy status of lactating dairy cows twenty-seven days after timed artificial insemination. J. Dairy Sci. 90:4612-4622.

Smyth, G. K. 2004. Linear models and empirical Bayes methods for assessing differential expression in microarray experiments. Stat. Appl. Genet. Mol. Biol. 3:3.

Sudo, N., T. Shimizu, C. Kawashima, E. Kaneko, M. Tetsuka, and A. Miyamoto. 2007. Insulin-like growth factor-I (IGF-I) system during follicle development in the bovine ovary: Relationship among IGF-I, type 1 IGF receptor (IGFR-1) and pregnancy-associated plasma protein-A (PAPP-A). Mol. Cell. Endocrinol. 264:197-203.

Telugu, B. P. V. F., A. M. Walker, and J. A. Green. 2009. Characterization of the bovine pregnancy-associated glycoprotein gene family-Analysis of gene sequences, regulatory regions within the promoter and expression of selected genes. BMC Genomics 10:185.

Thatcher, W. W., R. L. De la Sota, E. J.-P. Schmitt, T. Diaz, L. Badinga, and F. A. Simmen. 1996. Control and management of ovarian follicles in cattle to optimize fertility. Reprod. Fertil. Dev 8:203-217.

Thompson, I. M., R. L. A. Cerri, I. H. Kim, J. A. Green, J. E. P. Santos, and W. W. Thatcher. 2010. Effects of resynchronization programs on pregnancy per artificial insemination, progesterone and pregnancy-associated glycoproteins in plasma of lactating dairy cows. J. Dairy Sci. 93:4006-4018.

Weems, Y. S., P. J. Bridges, B. R. LeaMaster, R. G. Sasser, D. L. Vincent, and C. W. Weems. 1999. Secretion of progesterone, estradiol17beta, $\mathrm{PGE}, \mathrm{PGF}_{2 \alpha}$, and pregnancy-specific protein B by 90 -day intact and ovariectomized pregnant ewes. Prostaglandins Other Lipid Mediat. 58:139-148.

Weems, Y. S., L. Kim, V. Humphreys, V. Tsuda, and C. W. Weems. 2003. Effect of luteinizing hormone (LH), pregnancy specific protein B (PSPB), or arachidonic acid (AA) on ovine endometrium of the estrous cycle or placental secretion of prostaglandins E2 $(\mathrm{PGE} 2)$ and $\mathrm{F} 2$ alpha $\left(\mathrm{PGF}_{2 \alpha}\right)$ and progesterone in vitro. Prostaglandins Other Lipid Mediat. 71:55-73

Weems, Y. S., M. A. Lammoglia, H. R. Vera-Avila, R. D. Randel, C. King, C. R. G. Sasser, and C. W. Weems. 1998b. Effect of luteinizing hormone (LH), PGE2, 8-EPI-PGE1, 8-EPI-PGE2, trichosanthin, and pregnancy specific protein B (PSPB) on secretion of progesterone in vitro by corpora lutea (CL) from nonpregnant and pregnant cows. Prostaglandins Other Lipid Mediat. 55:27-42.

Weems, Y. S., M. A. Lammoglia, H. R. Vera-Avila, R. D. Randel, R. G. Sasser, and C. W. Weems. 1998a. Effects of luteinizing hormone (LH), PGE2, 8-Epi-PGE1, 8-Epi-PGF2 alpha, trichosanthin and pregnancy specific protein $\mathrm{B}$ (PSPB) on secretion of prostaglandin $(\mathrm{PG}) \mathrm{E}(\mathrm{PGE})$ or $\mathrm{F} 2$ alpha $\left(\mathrm{PGF}_{2 \alpha}\right)$ in vitro by corpora lutea (CL) from nonpregnant and pregnant cows. Prostaglandins Other Lipid Mediat. 55:359-376.

Wiltbank, M., H. Lopez, R. Sartori, S. Sangsritavong, and A. Gumen. 2006. Changes in reproductive physiology of lactating dairy cows due to elevated steroid metabolism. Theriogenology 65:17-29.

Wooding, F. B. P., R. M. Roberts, and J. A. Green. 2005. Light and electron microscope immunocytochemical studies of the distribution of pregnancy associated glycoproteins (PAGs) throughout pregnancy in the cow: Possible functional implications. Placenta 26:807-827.

Wu, Z., R. A. Irizarry, R. Gentleman, F. M. Murillo, and F. Spencer. 2004. A model based background adjustment for oligonucleotide expression arrays. J. Am. Stat. Assoc. 99:909-917.

Zoli, A. P., L. A. Guilbault, P. Delahaut, W. B. Ortiz, and J. F. Beckers. 1992. Radioimmunoassay of a bovine pregnancy-associated glycoprotein in serum: Its application for pregnancy diagnosis. Biol. Reprod. 46:83-92. 